\title{
Rancang Bangun Sistem Pencampur Bahan Minuman Bersoda Berdasarkan Kadar Keasaman Berbasis PLC OMRON CP1H-XA40DR-A
}

\author{
Rindi Kusumawardani* ${ }^{1}$, Raden Sumiharto ${ }^{2}$ \\ ${ }^{1}$ Prodi Elektronika dan Instrumentasi JurusanIlmuKomputerdanElektronika, FMIPA UGM \\ ${ }^{2}$ Jurusan IlmuKomputerdanElektronika, FMIPA UGM \\ e-mail: *11 rindikusumawardani@gmail.com, ${ }^{2}{ }^{2}$ _sumiharto@mail.ugm.ac.id
}

\begin{abstract}
Abstrak
Telah dibuat purwarupa sistem pencampur bahan minuman bersoda berdasarkan kadar keasaman berbasis PLC OMRON CP1H-XA4ODR-A. Pembuatan sistem ini didasari oleh pentingnya kadar $\mathrm{pH}$ dari bahan minuman bersoda, karena kadar $\mathrm{pH}$ pada suatu minuman sangat mempengaruhi kualitas dari minuman tersebut. Sistem pencampuran bahan minuman ini juga mempunyai Human Machine Interface (HMI) sebagai perantara kontrol dan masukan pada sistem. Keakuratan tinggi diperlukan dalam proses pencampuran bahan minuman bersoda untuk menjaga kualitas dari produk tersebut. Salah satu faktor yang diperhatikan untuk menjaga kualitas tersebut adalah dengan memastikan pH cairan dari hasil pencampuran sesuai dengan standar produksi. Sistem otomasi pencampuran bahan minuman bersoda yang diteliti ini berbasis pada PLC buatan OMRON dengan seri CP1H-XA40DR-A. Sistem ini dilengkapi dengan sensor ketinggian eTape sebagai sensor pendeteksi ketinggian, motor washer sebagai media penyemprot cairan, serta sensor elektroda pH PE-03 sebagai pembaca kadar keasaman..

Hasil dari penelitian ini adalah sebuah sistem pencampuran bahan minuman bersoda secara otomatis yang dapat mencampurkan cairan sesuai masukan pH yang ditentukan oleh pengguna. Terdapat rentang pilihan kadar keasaman yang tersedia dalam sistem ini, yaitu pH 4 sampai pH 6. Keakuratan proses pencampuran cairan ini yaitu sebesar $98,45 \%$.
\end{abstract}

Kata kunci-sistem pencampuran, PLC, sensor elektroda pH, HMI

\section{Abstract}

Have been made a prototype of soft drinks mixing ingredients system based on acidity controled by PLC OMRON CPIH-XA4ODR-A. This system have been made based on the importance of $p H$ levels on soft drinks. This mixing ingredients system has Human Machine Interface (HMI) for control and input on the system. High accuracy is needed in the process of mixing the ingredients of soft drinks to mantain the quality of the product. One of the factor that is considered to mantain it quality is to ensure $\mathrm{pH}$ levels of the mixing to standard production. The automation of soft drinks mixing ingredients systems is based on PLC by OMRON with serial number CPIH-XA40DR-A. This system equipped with eTape height sensor to detect height of the fluid, motor washer to pump the fluid, pH electrode PE-03 sensor to read the acidity.

The results of this study is a soft drinks mixing ingredients systems that automatically mixes the fluid according to the $\mathrm{pH}$ input by user. There are a range of acidity options available in this system, pH 4 to $\mathrm{pH} 6$. The accuracy of the fluid mixing process is equal to $98,45 \%$.

Keywords - mixing system, PLC, pH electrode sensors, HMI

Received January 21 ${ }^{\text {th }} 2014$; Revised August 21 ${ }^{\text {th }}$, 2014; Accepted April 15 ${ }^{\text {th }}, 2015$ 


\section{PENDAHULUAN}

$\mathrm{D}$ alam suatu proses produksi minuman, sebuah produk biasanya dibuat dari beberapa macam bahan yang memiliki komposisi dengan batas $\mathrm{pH}$ tertentu. Pengendalian kadar $\mathrm{pH}$ pada pencampuran minuman bersoda sangat diperlukan, karena kadar $\mathrm{pH}$ pada suatu minuman sangat mempengaruhi kualitas dari minuman tersebut. Menurut Peraturan Menteri Kesehatan RI No.722/Menkes/ Per/IX/1988 tentang Bahan Tambahan Makanan, pengatur keasaman adalah bahan tambahan makan yang dapat mengasamkan, menetralkan, dan mempertahankan derajat keasaman, seperti komposisi yang ada pada minuman bersoda. Oleh karena itu dibuat sistem pencampuran bahan pada minuman bersoda agar berada pada derajat keasaman PH yang diinginkan. Hal ini tentu akan sulit bila harus dilakukan secara manual (terutama pada proses produksi skala besar).

Untuk menangani sistem ini digunakan sistem kontrol elektronik PLC (Programmable Logic Controller), di mana dengan menggunakan PLC semua proses di industri menjadi lebih singkat karena waktu proses pengerjaan dengan PLC lebih menghemat waktu daripada dengan tenaga manusia yang memiliki keterbatasan dalam ketahanan bekerja. Semakin kompleks suatu sistem otomasi semakin penting pula penggunaan PLC untuk mempermudah dalam menjalankan proses otomasi tersebut [1].

Akan tetapi sistem otomasi tersebut tidak dapat di pantau dan diambil datanya secara langsung. Oleh karena itu pengawasan sebuah sistem akan lebih efektif jika sistem tersebut dilengkapi dengan Human Machine Interface (HMI), karena HMI dapat mengontrol sekaligus mengawasi kerja dari plant yang berjalan.

\section{METODE PENELITIAN}

\subsection{Analisis Sistem}

Sistem yang dibuat merupakan sebuah rancang bangun sistem pencampur bahan minuman bersoda. Rancang bangun ini berfungsi untuk mencampur dua buah cairan yang memiliki kadar keasaman yang berbeda agar menghasilkan sebuah campuran sesuai dengan kadar keasaman yang diinginkan.

\subsection{Perancangan Sistem}

Gambar 1 merupakan gambar blok diagram sistem keseluruhan. Gambar tersebut menjelaskan bahwa PLC OMRON CP1H berindak sebagai pengendali utama sistem, dimana input dari sistem berupa sensor eTape sebagai sensor untuk membaca ketinggian cairan yang kemudian akan diubah menjadi volume cairan [2]. Sensor elektroda pH PE-03 sebagai sensor untuk membaca $\mathrm{pH}$ pada campuran [3]. Sebagai aktuator sistem terdapat motor pengaduk, pompa 1 yang akan mengalirkan cairan 1 ke tangki pencampur dan pompa 2 yang akan mengalirkan cairan 2 ke tangki pencampur.

Human Machine Interface (HMI) yang digunakan pada sistem ini adalah Wonderware InTouch 10.0. HMI digunakan untuk mempermudah operator untuk memantau dan berkomunikasidengan plant serta mempercepat dalam penanganan jika terjadi gangguan pada sistem.

Kemudian untuk komunikasi antara PLC dan HMI digunakan komunikasi serial dengan perangkat lunak OPC CX Server dengan melakukan konfigurasi pada OPC CX Server dan pada System Managemant Console pada Wonderware sehingga PLC dan HMI dapat berkomunikasi [4].

IJEIS Vol. 5, No. 1, April 2015: 55 - 64 


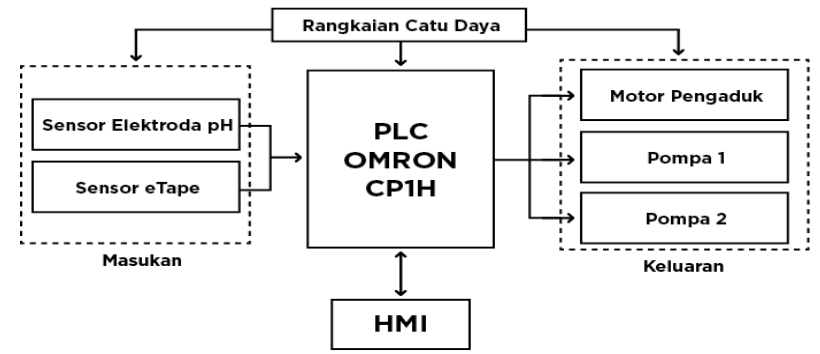

Gambar 1 Blok diagram sistem keseluruhan

\subsection{Implementasi Mekanik Sistem}

Mekanik terdiri dari sebuah papan berbahan dasar acrylic yang berfungsi untuk menempatkan 3 buah tabung yang terbuat dari plasti, dimana 2 tabung sebagai tabung bahan yang memiliki diameter $10 \mathrm{~cm}$ dan tinggi $13 \mathrm{~cm}$ dengan volume cairan yang dapat ditampung adalah 1020,5 ml, dan 1 buah tabung pencampuran yang memiliki diameter $15 \mathrm{~cm}$ dan tinggi $16 \mathrm{~cm}$ dengan volume cairan yang dapat ditampung adalah $2826 \mathrm{ml}$. Terdapat pula motor DC untuk menggerakan pengaduk cairan serta dua buah pompa yang menempel pada kedua buah tabung bahan. Gambar 2 menunjukkan implementasi dari sistem mekanik secara keseluruhan.

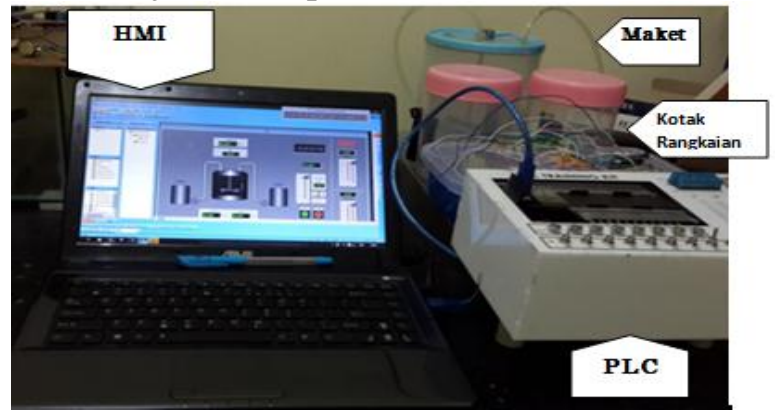

Gambar 2 Implementasi mekanik sistem

\subsection{Implementasi Perangkat Keras Sistem}

Implentasi dari perangkat keras yang dibahas pada sistem ini adalah rangkaian pengkondisian sinyal sensor elektroda $\mathrm{pH}$. Gambar 3 menunjukkan skematik rangkaian pengkondisian sinyal dengan menggunakan IC op-amp TL082 yang memiliki impedansi masukan yang tinggi yaitu $10^{12} \Omega$. Gambar 4 menunjukkan implementasi dari rangkaian pengkondisian sinyal, pengkondisian sinyal ini menggunakan 3 macam aplikasi op-amp yaitu rangkaian buffer, penguat penjumlah /Summing Amplifier dan penguat Inverting.. Karena keluaran tegangan dari sensor yang kecil (berorde milivolt) dengan rentang perubahan $\mathrm{pH}$ pada suatu larutan sekitar $-400 \mathrm{mV}$ untuk $\mathrm{pH} 14$ dan $400 \mathrm{mV}$ untuk $\mathrm{pH} 0$ maka diperlukan rangkaian penjumlah yang dapat mengubah tegangan negatif tersebut menjadi tegangan positif kemudian dikuatkan oleh rangkaian penguat inverting. Penguat ini dirancang dengan masukan inverting karena output dari rangkaian penjumlah adalah negatif, sehingga output dari rangkaian penguat bernilai positif yang akan masuk ke ADC PLC pada range 0-10V[5].

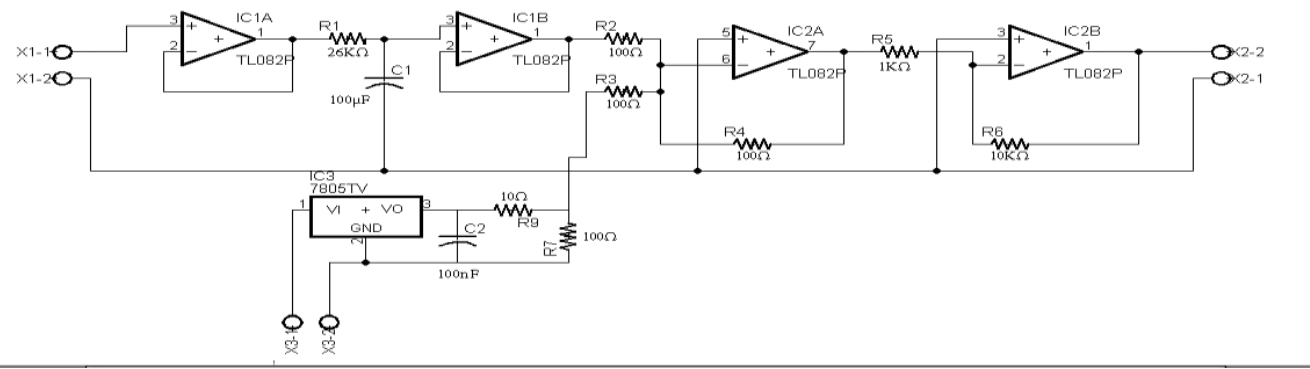

Gambar 3 Implementasi skematik rangkaian pengkondisian sinyal 


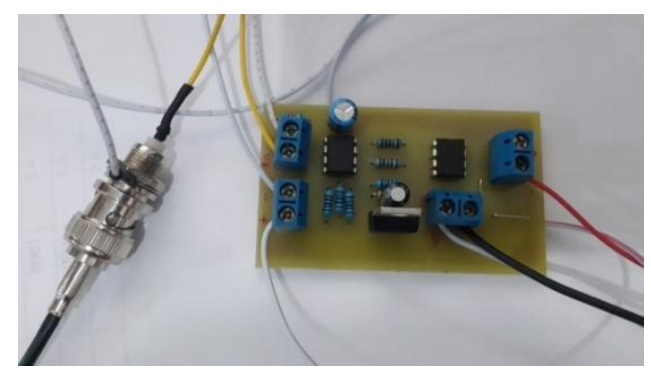

Gambar 4 Impelentasi rangkaian pengkondisian sinyal

\subsection{Implementasi Perangkat Lunak Sistem}

Perangkat lunak yang digunakan dalam sistem ini menggunakan ladder diagram dengan menggunakan perangkat lunak $C X$-Programmer untuk pemrograman pada PLC OMRON CP1H-XA40DR-A. Selain itu digunakan perangkat lunak Wonderware InTouch sebagai HMI yang ditunjukkan pada Gambar 5. Pada gambar tersebut terdapat 3 buah animasi tangki dimana 2 buah tangki sebagai tangki bahan dan 1 buah tangki sebagai tangki pencampuran, terdapat indikator cairan 1 dan 2 untuk membaca volume cairan yang keluar pada tiap tangki dan indikator volume serta $\mathrm{pH}$ yang digunakan untuk membaca volume keseluruhan pada proses pencampuran bahan dan pembacaan perubahan $\mathrm{pH}$ pada saat proses pencampuran berlangsung. Terdapat slider yang berfungsi untuk memasukkan nilai $\mathrm{pH}$ yang diinginkan pada proses pencampuran serta tombol start untuk menyalakan sistem dan tombol stop untuk mematikan sisrem.

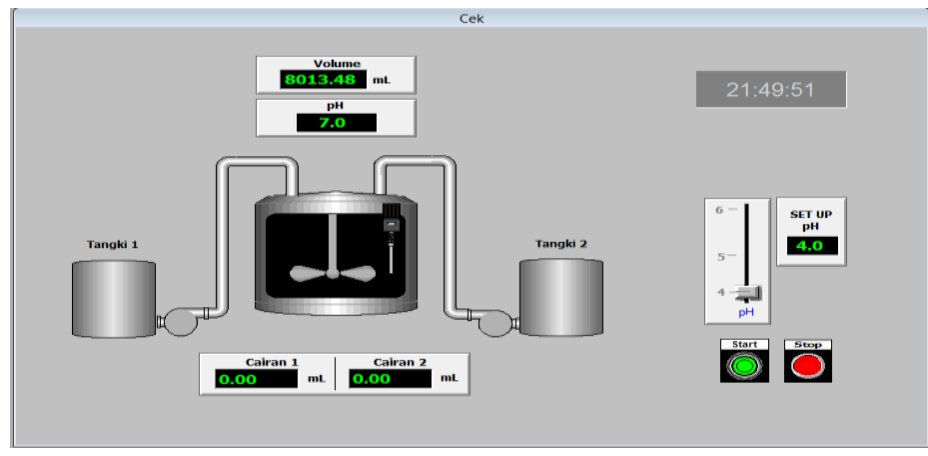

Gambar 5 Implemantasi grafis pada HMI

\section{HASIL DAN PEMBAHASAN}

Pada sistem ini dilakukan 4 macam pengujian, yaitu pengujian rangkaian pengkondisian sinyal sensor elektroda $\mathrm{pH}$, pengujian rangkaian sensor eTape, pengujian volume yang dikeluarkan, dan pengujian sistem secara keseluruhan

Pengujian rangkaian pengkondisian sinyal sensor elektroda $\mathrm{pH}$ bertujuan untuk mengetahui hasil keluaran dari rangkain penguat pada sensor elektroda. Pengujian rangkaian sensor eTape bertujuan untuk mengetahui jumlah tegangan yang dihasilkan terhadap perubahan dari variasi level cairan. Pengujian volume yang dikeluarkan bertujuan untuk menguji rumus dari kalibrasi sensor eTape untuk mengetahui hasil dari perhitungan rumus volume cairan yang dihasilkan.

\subsection{Pengujian rangkaian pengkondisian sinyal sensor elektroda $p H$}

Pada sensor elektroda $\mathrm{pH}$ yang memiliki keluaran berorder milivolt ini membutuhkan rangkaian pengkondisian sinyal agar bisa dibaca oleh ADC. Rangkaian pengkondisian sinyal ini dibuat untuk menguatkan sinyal keluaran dari sensor elektroda $\mathrm{pH}$ agar bisa terbaca oleh ADC pada PLC.

IJEIS Vol. 5, No. 1, April 2015 : $55-64$ 
Pengkondisian sinyal ini menggunakan 3 macam aplikasi op-amp yaitu rangkaian buffer, penguat penjumlah /Summing Amplifier dan penguat Inverting. Karena keluaran tegangan dari sensor yang kecil (berorde milivolt) dengan rentang perubahan $\mathrm{pH}$ pada suatu larutan sekitar $-400 \mathrm{mV}$ untuk $\mathrm{pH} 14$ dan $400 \mathrm{mV}$ untuk $\mathrm{pH} 0$ maka digunakan rangkaian penjumlah yang dapat mengubah tegangan negatif tersebut menjadi tegangan positif kemudian dikuatkan oleh rangkaian penguat inverting. Penguat ini dirancang dengan masukan inverting karena output dari rangkaian penjumlah adalah negatif, sehingga output dari rangkaian penguat bernilai positif yang akan masuk ke ADC PLC pada range 0-10V. Dengan menggunakan data keluaran sensor elektroda $\mathrm{pH}$ yang didapatkan pada pengujian sensor, keluaran dari rangkaian dapat dihitung dengan cara mengalikan tegangan keluaran sensor elektroda $\mathrm{pH}$ dengan besar penguatan dari rangkaian pengkondisian sinyal. Nilai resistor yang digunakan untuk pembagi tegangan dalam sistem ini menggunakan $10 \mathrm{Ohm}$ dan $100 \mathrm{Ohm}$ dan masukan $5 \mathrm{~V}$ sehingga menghasilkan tegangan masukan sebesar $454 \mathrm{mV}$ yang kemudian digunakan sebagai penjumlah tegangan masukan dari sensor.Sehingga secara perhitungannya adalah apabila nilai input terkecil adalah $-400 \mathrm{mV}$ maka ditambahkan dengan tegangan sebesar $454 \mathrm{mV}$. Sehingga diperoleh hasil range tegangan $0,054 \mathrm{~V}$ sampai $0,854 \mathrm{~V}$. Kemudian hasil dari rangkaian penguat penjumlah dikuatkan oleh rangkaian penguat inverting dengan menggunakan resistor $10 \mathrm{kOhm}$ dan $1 \mathrm{kOhm}$ sehingga diperoleh perbesaran 10 kali. Keluaran dari pengkondisian sinyal tersebut yang akan masuk pada range ADC 0-10V.

Dari hasil pengujian tersebut diperoleh data perbandingan antara pengukuran dengan rangkaian pengkondisian sinyal yang masih berupa tegangan dan pengukuran dengan $\mathrm{pH}$ meter yang ditunjukkan pada Tabel 1. Dari tabel tersebut menunjukkan data hasil dari pengukuran $\mathrm{pH}$ meter dan rangkaian pengkondisian sinyal serta ADC yang belum dikalibrasi. $\mathrm{pH}$ meter menunjukkan hasil pengukuran dalam satuan $\mathrm{pH}$ sedangkan rangkaian pengkondisian sinyal menunjukkan hasil pengukuran dalam satuan voltage yang sudah dikuatkan 10 kali.Data diperoleh dari variasi larutan dengan kadar asam dan basa yang berbeda. Untuk $\mathrm{pH}$ terbesar/ basa diperoleh dari pengukuran larutan $\mathrm{CH}_{3} \mathrm{COOH}$ dengan air, untuk larutan netral (pH 7) diukur dengan menggunakan cairan buffer yang memiliki $\mathrm{pH} 7$, sedangkan untuk $\mathrm{pH}$ terendah diperoleh dari larutan $\mathrm{NaOH}$ dengan air.

Tabel 1 Data pembacaan $\mathrm{pH}$ meter dengan rangkaian pengkondisian sinyal

\begin{tabular}{|c|c|c|}
\hline No. & pH Meter & Output Pengkondisian Sinyal (volt) \\
\hline 1. & 2,34 & 6,7 \\
\hline 2. & 3,04 & 6,32 \\
\hline 3. & 4,05 & 5,78 \\
\hline 4. & 5,06 & 5,23 \\
\hline 5. & 6,05 & 4,68 \\
\hline 6. & 7,05 & 4,16 \\
\hline 7. & 8,09 & 3,6 \\
\hline 8. & 9,47 & 2,84 \\
\hline 9. & 10,12 & 2,47 \\
\hline 10. & 11,19 & 1,91 \\
\hline 11. & 12,03 & 1,45 \\
\hline 12. & 13,4 & 0,69 \\
\hline
\end{tabular}


Gambar 6 menunjukkan grafik dari perubahan $\mathrm{pH}$ meter terhadap keluaran dari pengkondisian sinyal sensor elektroda $\mathrm{pH}$.

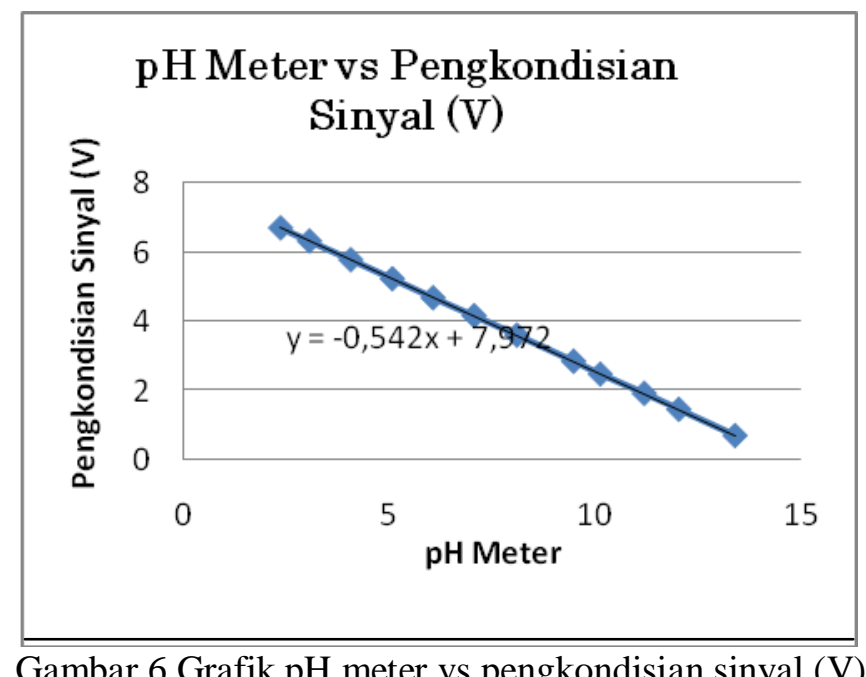

\subsection{Pengujian rangkaian sensor eTape}

Rangkaian sensor eTape ini menggunakan rangkaian pembagi tegangan untuk mengubah keluaran sensor dari hambatan menjadi tegangan. Sensor eTape ini memiliki perubahan hambatan antara 800-1500 ohm berdasarkan ketinggian air di dalam tangki. Persamaan (1) menunjukkan perhitungan dari rangkaian pengkondisian sinyal pada saat tangki air kondisi kosong $(0 \mathrm{~cm})$

$$
\begin{aligned}
& \text { Vout }=\frac{\text { Vdd } \times R 2}{\text { Rref }+R 2} \\
&= \frac{9 \times 1500}{1500+1500} \\
&=4,5 \text { volt }
\end{aligned}
$$

Persamaan (2) menunjukkan perhitungan dari rangkaian pengkondisian sinyal pada saat tangki air kondisi penuh $(15 \mathrm{~cm})$

$$
\begin{aligned}
\text { Vout } & =\frac{\text { Vdd } \times \mathrm{R} 2}{\begin{array}{c}
\text { Rref }+\mathrm{R} 2 \\
9 \times 800
\end{array}} \\
& =\frac{1500+800}{} \\
& =3,13 \text { volt }
\end{aligned}
$$

Rref adalah resistor referensi pada eTape yang bernilai $1500 \mathrm{Ohm}$ dan $\mathrm{r} 2$ merupakan sensor eTape yang hambatannya berubah- ubah 800-1500 ohm, tergantung ketinggian air di dalam tangki. Pada perhitungan rumus pembagi tegangan diatas dihasilkan range tegangan keluaran sebesar 3,13 V- 4,5 V. Tegangan keluaran dari pembagi tegangan inilah yang akan menjadi masukan analog di PLC CP1H. Tabel 2 menunjukkan hasil pengujian nilai tegangan yang diberikan oleh sensor terhadap perubahan ketinggian air. Pengujian dilakukan dengan melakukan variasi ketinggian air pada saat tangki kosong kemudian di variasikan dengan ketinggian tiap $\mathrm{cm}$ sampai pada ketinggian maksimal tangki pencampuran yaitu $15 \mathrm{~cm}$. Dilakukan pengamatan terhadap perubahan tegangan yang dihasilkan sensor.

Dari grafik Gambar 7 dapat dilihat perubahan nilai tegangan terhadap perubahan ketinggian air ada linear. Grafik tersebut memiliki persamaan $y=-0,089 x+4,617$. Alat ukur 
ketinggian yang digunakan untuk pengamatan adalah sebuah penggaris dengan ketelitian sebesar $\pm 0,5 \mathrm{~mm}$. Tangki pada kondisi kosong mempunyai nilai tegangan yang paling tinggi yaitu 4,37 V sedangkan tangki pada kondisi penuh memiliki nilai tegangan paling rendah yaitu $3,18 \mathrm{~V}$. Tegangan keluaran pembagi tegangan saat tangki kosong dan saat tangki penuh berbeda dengan hasil yang diperoleh saat dilakukan pengamatan. Berdasarkan perhitungan yang telah dilakukan, range tegangan keluaran adalah $3,13 \mathrm{~V}-4,5 \mathrm{~V}$ sedangkan setelah dilakukan pengamatan range keluarannya menjadi $3,17 \mathrm{~V}-4,37 \mathrm{~V}$. Hal tersebut disebabkan karena menurut datasheet, sensor eTape memiliki ralat sebesar $\pm 10 \%$.

Tabel 2 Perubahan nilai tegangan terhadap ketinggian air

\begin{tabular}{|c|c|c|c|c|c|}
\hline No. & Ketinggian Air (cm) & Tegangan (V) & No. & Ketinggian Air (cm) & Tegangan (V) \\
\hline 1. & 1 & 4,37 & 9. & 9 & 3,81 \\
\hline 2. & 2 & 4,37 & 10. & 10 & 3,71 \\
\hline 3. & 3 & 4,37 & 11. & 11 & 3,62 \\
\hline 4. & 4 & 4,37 & 12. & 12 & 3,55 \\
\hline 5. & 5 & 4,24 & 13. & 13 & 3,48 \\
\hline 6. & 6 & 4,13 & 14. & 14 & 3,34 \\
\hline 7. & 7 & 4,01 & 15. & 15 & 3,17 \\
\hline 8. & 8 & 3,94 & & & \\
\hline
\end{tabular}

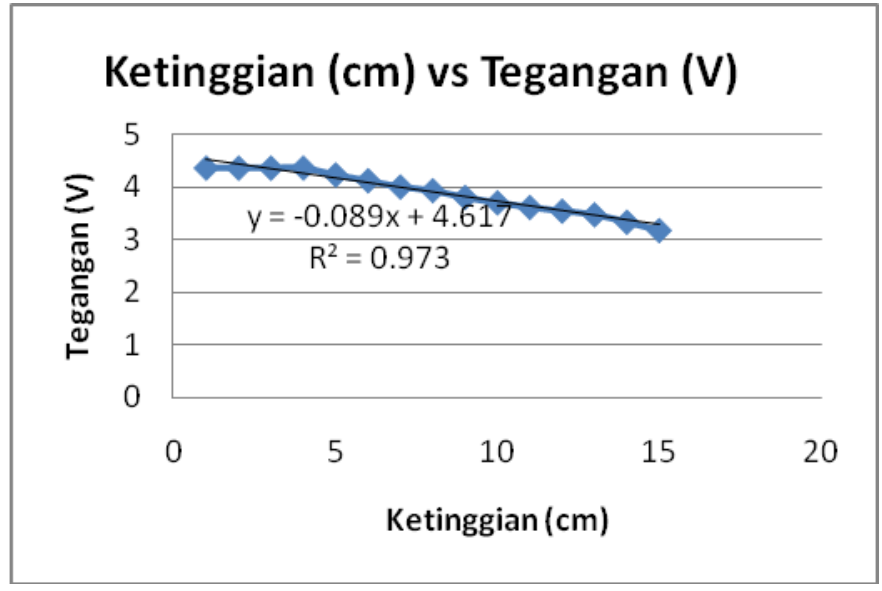

Gambar 7 Grafik ketinggian vs tegangan

\subsection{Pengujian volume yang dihasilkan}

Pengujian ini dilakukan untuk mengetahui hasil dari perhitungan rumus volume yang dihasilkan. Pengujian dilakukan dengan cara memasukkan nilai volume cairan yang diinginkan dibandingkan dengan hasil volume yang dikeluarkan sistem. Pengujian dilakukan sebanyak 5 kali dengan variasi masukan volume $500 \mathrm{ml}$ sampai dengan $2500 \mathrm{ml}$, karena karakteristik dari sensor eTape baru bisa membaca perubahan tegangan mulai pada ketinggian $4 \mathrm{~cm}$. Pengujian ini dilakukan untuk menguji rumus persamaan kalibrasi sensor eTape yang ada pada script di Wonderware InTouch.

Dari Tabel 3 yang menunjukkn perbandingan volume masukan dengan volume yang dihasilkan, diketahui antara masukan HMI dengan hasil keluarannya mempunyai error sebesar $6,50 \%$. Nilai error sistem diperoleh dari rata-rata nilai error tiang range. Nilai error yang terbesar berada pada volume $500 \mathrm{ml}$ sebesar $20,2 \%$, hal ini disebabkan karena karakteristik dari sensor eTape itu sendiri yang baru mengalami perubahan tegangan diatas ketinggian $4 \mathrm{~cm}$, sehingga cairan baru dapat terbaca dengan baik pada volume diatas $600 \mathrm{ml}$. Dari hasil error yang didapat sistem mempunyai ketepatan $93,50 \%$, sehingga diperoleh grafik pada Gambar 8 . 
Ketidaktepatan yang ada dikarenakan sensor eTape yang digunakan mempunyai keluaran yang tidak stabil, sehingga menyebabkan ADC pada PLC mengalami fluktuasi yang menyebabkan ketidaktepatan pengukuran.

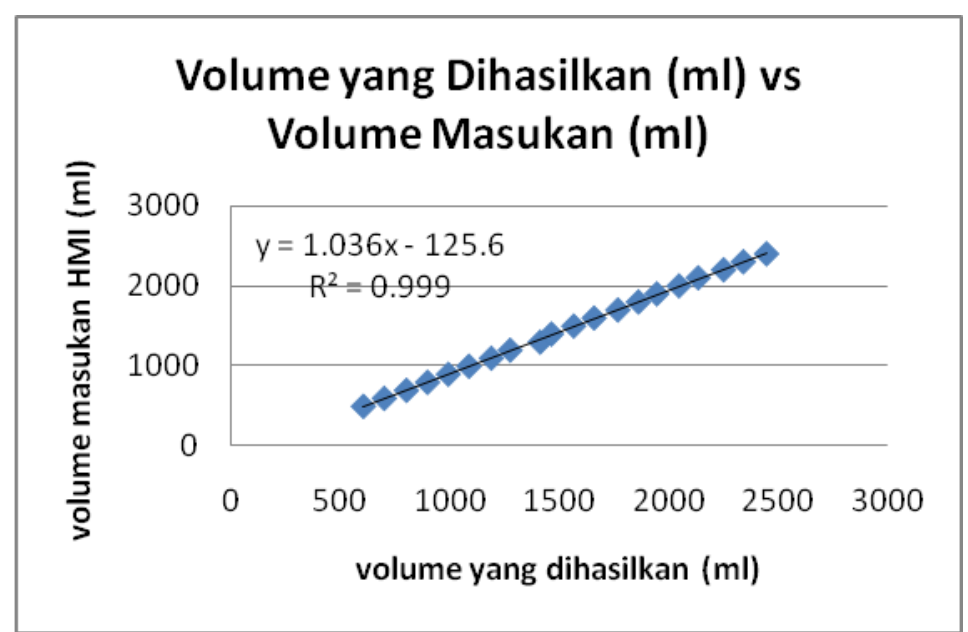

Gambar 8 Grafik perbandingan volume yang dihasilkan (ml) vs volume masukan HMI (ml)

Tabel 3 Perbandingan volume masukan dengan volume keluaran yang dihasilkan

\begin{tabular}{|c|c|c|c|c|c|c|c|c|}
\hline \multirow{2}{*}{ No. } & \multirow{2}{*}{$\begin{array}{c}\text { Volume masukan } \\
(\mathrm{mL})\end{array}$} & \multicolumn{7}{|c|}{ Volume yang Dihasilkan (mL) } \\
\hline & & $\begin{array}{c}\text { Data } \\
1\end{array}$ & $\begin{array}{c}\text { Data } \\
2\end{array}$ & $\begin{array}{c}\text { Data } \\
3\end{array}$ & $\begin{array}{c}\text { Data } \\
4\end{array}$ & $\begin{array}{c}\text { Data } \\
5\end{array}$ & $\begin{array}{c}\text { Rata- } \\
\text { rata }\end{array}$ & $\begin{array}{c}\text { Error } \\
(\%)\end{array}$ \\
\hline 1. & 500 & 568 & 620 & 616 & 591 & 610 & 601 & 20,2 \\
\hline 2. & 600 & 692 & 695 & 706 & 691 & 700 & 696,8 & 16,13 \\
\hline 3. & 700 & 802 & 785 & 808 & 804 & 795 & 798,8 & 14,11 \\
\hline 4. & 800 & 895 & 876 & 898 & 908 & 894 & 894,2 & 11,78 \\
\hline 5. & 900 & 988 & 977 & 980 & 997 & 1008 & 990 & 10 \\
\hline 6. & 1000 & 1086 & 1087 & 1099 & 1072 & 1081 & 1085 & 8,5 \\
\hline 7. & 1100 & 1176 & 1181 & 1179 & 1174 & 1175 & 1187 & 7,91 \\
\hline 8. & 1200 & 1266 & 1280 & 1275 & 1276 & 1270 & 1273,4 & 6,12 \\
\hline 9. & 1300 & 1400 & 1414 & 1425 & 1420 & 1394 & 1410,6 & 8,51 \\
\hline 10. & 1400 & 1461 & 1457 & 1464 & 1465 & 1465 & 1462,4 & 4,46 \\
\hline 11. & 1500 & 1562 & 1564 & 1561 & 1582 & 1554 & 1564,6 & 4,31 \\
\hline 12. & 1600 & 1672 & 1657 & 1658 & 1650 & 1651 & 1657,6 & 3,6 \\
\hline 13. & 1700 & 1767 & 1775 & 1792 & 1751 & 1747 & 1766,4 & 3,91 \\
\hline 14. & 1800 & 1862 & 1865 & 1855 & 1845 & 1878 & 1861 & 3,39 \\
\hline 15. & 1900 & 1958 & 1944 & 1938 & 1937 & 1948 & 1945 & 2,37 \\
\hline 16. & 2000 & 2042 & 2048 & 2047 & 2047 & 2050 & 2046,8 & 2,34 \\
\hline 17. & 2100 & 2138 & 2134 & 2134 & 2138 & 2129 & 2134,6 & 1,65 \\
\hline 18. & 2200 & 2241 & 2246 & 2254 & 2267 & 2244 & 2250,4 & 2,29 \\
\hline 19. & 2300 & 2383 & 2341 & 2326 & 2326 & 2331 & 2341,4 & 1,8 \\
\hline 20. & 2400 & 2458 & 2464 & 2468 & 2425 & 2420 & 2447 & 1,96 \\
\hline 21. & 2500 & 2542 & 2532 & 2537 & 2521 & 2531 & 2532,6 & 1,30 \\
\hline & ror & & & & & & & 6,50 \\
\hline
\end{tabular}




\subsection{Pengujian sistem secara keseluruhan}

Pengujian ini meliputi pengujian pencampuran bahan dengan memasukkan nilai $\mathrm{pH}$ yang berbeda-beda dari $\mathrm{pH} 4$ sampai $\mathrm{pH}$ 6. Dengan volume cairan 1 tetap yaitu 702,6ml dan volume cairan 2 yang didapat dari hasil pembacaan $\mathrm{pH}$ sehingga akan didapat volume akhir dari pencampuran bahan. Pengujian ini dilakukan untuk menguji rumus kalibrasi sensor elektroda pH. Gambar 9 merupakan grafik dari tabel hasil pengujian sistem. Dari Tabel 4 Diketahui antara masukan HMI dengan hasil keluarannya mempunyai error sebesar $1,55 \%$. Nilai error sistem diperoleh dari rata-rata nilai error tiang range. Sehingga sistem mempunyai ketepatan $98,45 \%$.

Tabel 4 Pengujian masukan $\mathrm{pH}$ dengan hasil pencampuran

\begin{tabular}{|c|c|c|c|c|c|}
\hline \multirow[t]{2}{*}{$\begin{array}{c}\text { Masukan } \\
\text { pH }\end{array}$} & \multicolumn{5}{|c|}{$\begin{array}{c}\text { pH } \\
\text { Campuran }\end{array}$} \\
\hline & Data 1 & Data 2 & Data 3 & $\begin{array}{c}\text { Rata- } \\
\text { rata }\end{array}$ & $\begin{array}{c}\text { Error } \\
(\%)\end{array}$ \\
\hline 4,05 & 4,08 & 4,05 & 4,04 & 4,06 & 0,67 \\
\hline 4,1 & 4,11 & 4,15 & 4,08 & 4,11 & 1,33 \\
\hline 4,2 & 4,22 & 4,16 & 4,19 & 4,19 & 1 \\
\hline 4,31 & 4,34 & 4,29 & 4,3 & 4,31 & 0 \\
\hline 4,4 & 4,4 & 4,42 & 4,39 & 4,4 & 0,33 \\
\hline 4,5 & 4,47 & 4,47 & 4,49 & 4,48 & 2,33 \\
\hline 4,61 & 4,61 & 4,58 & 4,6 & 4,59 & 1,33 \\
\hline 4,7 & 4,69 & 4,71 & 4,69 & 4,69 & 0,33 \\
\hline 4,82 & 4,81 & 4,8 & 4,81 & 4,81 & 1,33 \\
\hline 4,91 & 4,91 & 4,89 & 4,9 & 4,9 & 1 \\
\hline 5 & 4,99 & 4,97 & 4,99 & 4,98 & 1,67 \\
\hline 5,11 & 5,09 & 5,1 & 5,08 & 5,09 & 2 \\
\hline 5,21 & 5,17 & 5,2 & 5,19 & 5,19 & 2,33 \\
\hline 5,3 & 5,26 & 5,31 & 5,3 & 5,29 & 1 \\
\hline 5,41 & 5,4 & 5,38 & 5,4 & 5,39 & 1,67 \\
\hline 5,51 & 5,51 & 5,49 & 5,47 & 5,49 & 2 \\
\hline 5,6 & 5,63 & 5,61 & 5,59 & 5,61 & 1 \\
\hline 5,71 & 5,7 & 5.67 & 5,69 & 5,69 & 2,33 \\
\hline 5,81 & 5,78 & 5,75 & 5,78 & 5,77 & 4 \\
\hline 5,9 & 5,93 & 5,9 & 5,87 & 5,9 & 3 \\
\hline 6,05 & 5,93 & 5,97 & 6,03 & 5,98 & 2 \\
\hline \multicolumn{5}{|c|}{ Rata- rata Error } & 1,55 \\
\hline
\end{tabular}

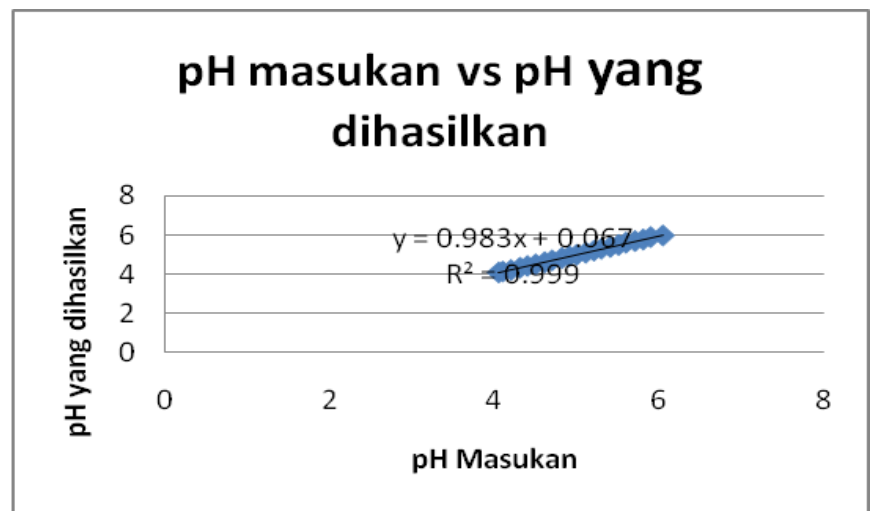

Gambar 9 Grafik perbandingan $\mathrm{pH}$ masukan dengan $\mathrm{pH}$ campuran sistem 


\section{KESIMPULAN}

1. Sistem pencampuran cairan bersoda menggunakan sensor elektroda $\mathrm{pH}$ dan sensor ketinggian eTape berbasis PLC Omron $\mathrm{CP} 1 \mathrm{H}$ yang dikontrol dan dipantau malalui HMI dapat diimplementasikan dan bekerja dengan baik.

2. Set point $\mathrm{pH}$ dapat diatur sesuai kebutuhan melalui HMI.

3. HMI mempermudah operator berkomunikasi dengan plant,serta mempercepat penanganan jika terjadi gangguan pada sistem.

4. Sistem pencampuran bahan minuman bersoda berdasarkan kadar keasaman ini mempunyai ketepatan $98,45 \%$

\section{SARAN}

Pada penelitian lebih lanjut perlu dilakukan penelitian yang lebih lanjut pada proses pencampuran cairan agar menghasilkan campuran yang sesuai dengan standar produksi di industri. Selain itu dibutuhkan jenis sensor yang memiliki ketelitian yang lebih tinggi dibandingkan sensor ketinggian yang digunakan saat ini.

\section{DAFTAR PUSTAKA}

[1] Wicaksono, Handy. 2012. SCADA Software dengan Wonderware InTouch. Yogyakarta: Graha Ilmu.

[2] MiloneTech, Continuous Fluid Level Sensor PN 12110215TC-8. Datasheet.

[3] Hall, D. G. 1996. Ion-Selective Membrane Electrodes: A General Limiting Treatment of Interference Effect, J. Phys. Chem 100, 7230-7236.

[4] Invensys, 2004, Wonderware OPCLink User's Guide. pdf, Invesys System 26561 Rancho Parkway South Lake Forest.

[5] Omron, 2005, SYSMAC CP Series, CP1H CPU Unit Operational Manual. Omron Asia Pasific, Ltd. Singapore. 